\title{
MAKNA UPACARA BATIMBANG DALAM TRADISI MASYARAKAT SUKU BANJAR KUALA TUNGKAL, PROVINSI JAMBI
}

\author{
M. Syahran Jailani dan Nurhasanah \\ Universitas Islam Negeri (UIN) Sulthan Thaha Saifuddin Jambi email: \\ m.syahran@ymail.com; nurhasanah141116@gmail.com
}

\begin{abstract}
This paper discusses the batimbang traditional ceremony which is one form of the buman life cycle ceremony is conducted by urang Banjar Kuala Tungkal Jambi Province. This batimbang ceremony is only intended for baby (child) who born exactly the Safar month in the bijriyah month. Urang Banjar believing, baby (child) was born in the Safar month that is believed in the life ranging from baby to adult will be various experience calamities even some of the urang Banjar considers baby who born in the Safar month or bad month. Urang Banjar carry out this ceremony because they believe the Safar month as a bad month full of reinforcements and ways, and the misfortune of Safar month will befall the child's life. Batimbang means weighting. Something is weighed to be balanced and sufficient. Therefore, in order to avoid inflicting misfortune and distress to the child, so the child must be weighed as a form of ritual refusing reinforcement and recovery from unlucky circumstances.
\end{abstract}

Keywords: Batimbang ceremony, urang Banjar and life cycle

\begin{abstract}
Abstrak: Tulisan ini mengkaji tentang upacara adat batimbang yang merupakan salah satu bentuk upacara sikelus kehidupan manusia dilaksanakan oleh urang Banjar Kuala Tungkal Provinsi Jambi. Upacara batimbang ini hanya diperuntukan pada bayi (anak) yang labir tepat bulan Safar dalam penanggalan bulan bijriah. Kepercayaan urang Banjar, bayi (anak) yang labir di bulan Safar dipercayai dalam perjalanan kebidupannya mulai dari bayi bingga dewasa akan mengalami berbagai musibah babkan sebagian urang Banjar menganggap bayi yang labir di bulan Safar bulan na'as atau bulan kurang baik. Urang Banjar melaksanakan upacara ini karena mempercayai bulan Safar sebagai bulan sial yang penub bala dan bencara, dan kesialan bulan Safar akan menimpa kebidupan anak tersebut. Batimbang berarti ditimbang, agar seimbang dan cukup. Oleh karena itu untuk menghindari tertimpanya kesialan dan kesusahan pada anak tersebut, maka sang anak wajib ditimbang sebagai bentuk ritual tolak bala dan pemulihan dari keadaan sial.
\end{abstract}

Kata kunci: Upacara batimbang, urang Banjar dan sikelus kehidupan 


\section{Pendahuluan}

Urang (orang/suku) Banjar, adalah sebutan bagi penduduk yang terkonsentrasi di provinsi Kalimantan Selatan. Selain di Kalimantan Selatan, suku Banjar dalam catatan sejarah telah lama bermigrasi dan mendiami sebagian wilayah nusantara seperti Sumatera. Banjar adalah salah satu suku di Indonesia yang senang bermigrasi. Bermigrasi atau merantau dalam bahasa Banjar disebut dengan istilah madam. Madam merupakan satu bentuk migrasi di kalangan orang Banjar seperti tradisi merantau di kalangan etnik Minang (Sumatera Barat). Setelah terbukanya Kota Kuala-Tungkal (dulu masuk wilayah Sumatera Bagian Tengah) maka, semakin banyak orang Banjar bermigrasi ke Sumatera.

Orang-orang Banjar dari Kalimantan Selatan yang kemudian menjadi penduduk pendatang atau kelompok migran mayoritas di kawasan Kuala Tungkal dan sekitarnya. Tungkal Ilir adalah sebuah salah satu kecamatan di Kabupaten Tanjung Jabung Barat, Provinsi Jambi. Ibukota dari Kecamatan Tungkal Ilir sendiri adalah Kuala Tungkal yang juga ibukotaKabupaten Tanjung Jabung Barat berjarak $125 \mathrm{KM}$ dari Ibu Kota Provinsi Jambi.

Hairus Salim dalam jurnal Seloko Budaya, menemukan bukti bahwa orang Banjar telah cukup lama berdiam di Kuala-Tungkal. Jalur migrasi dari Kalimantan Selatan setidaknya: Pertama, sewaktu Tuan Guru Abdurrahman Shiddiq (Tuan Guru Sapat) yang berasal dari Banjar menjadi mufti di Indragiri, banyak orang Banjar yang kemudian ikut migrasi ke sana, termasuk ke Kuala Tungkal yang secara geografis satu jalur perairan dengan Indragiri. Kedua, orang Banjar awalnya pergi ke Johor Malaysia, dan dari sana kemudian menyeberang ke Kuala Tungkal. Karena itu, beberapa daerah di Kuala Tungkal memiliki nama yang sama dengan di Johor. Orang Banjar sendiri meyakini, jauh sebelum migrasi dua jalur itu, mereka juga sudah banyak yang menetap di Kuala Tungkal. ${ }^{1}$

Urang Banjar di Tungkal Ilir bertahan dalam ikatan adat istiadat, karena masyarakat adalah kesatuan hidup dari makhluk-makhluk manusia yang terikat oleh suatu sistem adat istiadat. Budaya Banjar dapat dilihat dari kehidupan sehari-hari masyarakat Banjar di Kuala-Tungkal. Demikian pula upacara adat khas Banjar yang biasanya dilaksanakan dalam rangka siklus kehidupan seperti perkawinan, kelahiran, kematian ataupun peringatan terhadap peristiwa penting lainnya.

${ }^{1}$ Dewan Kesenian Jambi, “"Editorial,” Seloko: Jurnal Budaya, 1, no. 2 (2012): ix. 
Makna Upacara Batimbang dalam Tradisi Masyarakat Suku Banjar Kuala Tungkal, Provinsi Jambi

Upacara siklus kehidupan pada tahap kelahiran yang masih dilaksanakan oeh urang Banjar di Kuala-Tungkal dalah Upacara Batimbang. Masyarakat Banjar yang menetap di Tungkal Iilir sebagaimana masyarakat lainnya di Indonesia, mereka mempercayai bahwa kehidupan manusia selalu diiringi dengan masa-masa kritis, yaitu suatu masa yang penuh dengan ancaman dan bahaya Masa-masa itu adalah peralihan dari tingkat kehidupan yang satu ke tingkat kehidupan lainnya (dari manusia masih berupa janin sampai meninggal dunia). Oleh karena masa-masa tersebut dianggap sebagai masa yang penuh dengan ancaman dan bahaya, maka diperlukan adanya suatu usaha untuk menetralkannya, sehingga dapat dilalui dengan selamat. Usaha tersebut diwujudkan dalam bentuk upacara yang kemudian dikenal sebagai upacara lingkaran hidup individu yang meliputi: kelahiran, perkawinan, dan kematian.

Orang Banjar di Tungkal Ilir mengenal beberapa upacara peralihan/inisiasi masa kelahiran, diantaranya adalah ritual "batimbang" anak kelahiran bulan Safar, upacara komunal yang telah mentradisi di kalangan masyarakat Banjar di Tungkal Ilir yang dilaksanakan untuk peristiwa penting dalam kehidupan seseorang. Ritual ini dilakukan atau dikenakan pada bayi yang lahir di bulan Safar. Menurut keyakinan tradisional orang Banjar, jika seseorang dilahirkan di bulan Safar, orang itu akan memiliki tabiat yang buruk. Keluarga anak tersebut terutama ibu dan bapaknya perlu melakukan ritual batimbang untuk menghilangkan tabiat buruk itu, jika tidak, kehidupannya akan menjadi susah di kemudian hari. Hal ini juga tidak terlepas dari kepercayaan masyarakat tentang bulan Safar yang diyakini banyak keburukan, bala dan bencana. ${ }^{2}$

Tradisi batimbang dilakukan sebagai suatu permohonan agar si anak diselamatkan dari gangguan dan bencana yang mengancam hidup dan kehidupannya. Melalui ritual ini, manusia merasa terlindungi oleh kekuatan maha besar yaitu Allah sebagai kekuatan penyelamat. Dalam upacara batimbang tersebut terdapat peralatan, dan perlengkapam yang dijadikan sarana untuk menjembatani komunikasi antara manusia dengan kekuatan penyelamat yang diinginkan.

Dalam artikel ini, penulis berupaya menggali nilai-nilai budaya masyarakat Banjar di Kuala-Tungkal yang masih hidup dan berkembang khususnya dalam hal tradisi batimbang. Meski telah memasuki era modern, batimbang masih dilakukan karena alasan merasa belum tenang kalau

${ }^{2}$ Bulan Shafar adalah bulan kedua dalam kalender Hijriyah. 
belum melaksanakan tradisi ini, khawatir kalau terjadi hal-hal yang tidak diinginkan, menimpa sang anak dan keluarganya, walaupun secara sosial religius telah menjalankan semua syariat agamanya. Batimbang menurut keyakinan masyarakat Banjar di Tungkal Ilir merupakan suatu keharusan.

\section{Sekitar Upacara Adat Batimbang}

Upacara adat batimbang merupakan salah satu upacara siklus hidup individu yang dilaksanakan oleh urang Banjar yang bermukim di Tungkal Ilir dan masih dilaksanakan oleh asal nenek moyang mereka di Kalimantan Selatan. Ritual ini dilakukan, karena menurut keyakinan tradisional orang Banjar, bulan Safar mempunyai pengaruh buruk terhadap perilaku dan watak seseorang yang terlahir di bulan ini. Jika seseorang dilahirkan di bulan Safar, orang itu diyakini akan memiliki tabiat yang buruk. Keluarga anak tersebut terutama ibu bapaknya perlu melakukan upacara ritual batimbang untuk menghilangkan tabiat buruk itu, jika tidak, kehidupannya akan menjadi susah di kemudian hari. ${ }^{3}$

Urang/suku Banjar beranggapan bulan Safar bulan sial, sehingga banyak yang tidak berani melakukan aktivitas penting dan perayaan di bulan ini, seperti mengadakan perkawinan, apabila dilanggar, perkawaninan orang yang dilaksanakan bulan tersebut bisa jadi tidak harmonis dan berujung pada perceraian. Perempuan hamil selalu berdoa agar tidak melahirkan di bulan Safar, apabila melahirkan di bulan Safar, anaknya harus ditimbang atau batimbang, jika tidak, dikhawatirkan menjadi nakal, bodoh, dan keras kepala. Pada bulan Safar ini urang Banjar tidak berani memulai membangun rumah, apabila dilanggar berakibat terjauh dari kedamaian, dan tidak berani memulai usaha, kalau dilanggar mengakibatkan kebangkrutan. ${ }^{4}$

Upacara adat batimbang berarti ditimbang. Ditimbang agar terjadi keseimbangan dan cukup. Artinya setiap anak yang lahir di bulan safar ditimbang agara anak tersebut tumbuh dan berkembang sebagimana harapan orang tua menjadi anak yang taat kepada agama dan orang tua. Dalam kepercayaan urang Banjar anak yang lahir di bulan Safar akan bebal, keras kepala atau kurang akal (tidak mau menerima/mendengar

${ }^{3}$ Wawancara dengan Pak Mahyuddin (55 th), 09 Oktober 2016. Kecamatan Tungkal Ilir.

${ }^{4}$ Wawancara dengan Ibu Arbaiyah (60 th), 10 Oktober 2016. Kecamatan Tungkal Ilir. 
Makna Upacara Batimbang dalam Tradisi Masyarakat Suku Banjar Kuala Tungkal, Provinsi Jambi

nasihat orang lain). Batimbang dapat juga berarti dipulihkan keseimbangannya atau dikembalikan dari keadaan yang kurang baik. Inti upacara ini adalah menolak bala bencana yang bisa saja menimpa pada diri seseorang karena dilahirkan di bulan naas, bulan yang dianggap kurang baik yang dapat menyebabkan bencana.

Upacara batimbang merupakan salah satu bagian dari rangkaian upacara adat yang dimodifikasi dengan menggunakan metode akulturasi, dalam tradisi ini terjadi persilangan antara budaya Banjar dengan ajaran Islam, yaitu penggabungan antara budaya khas banjar "batimbang" dengan memasukkan nilai-nilai religi. Upacara atau tradisi suku Banjar berlaku bagi warga masyarakat yang berdomisili di Kuala-Tungkal atau Tungkal Ilir maupun tempat nenek moyang urang (orang) Banjar di Kalimantan Selatan.

Upacara batimbang diarahkan pada tranformasi keadaan manusia. Tujuannya adalah untuk menjamin perubahan menyeluruh pada keadaan akhir yang diinginkan oleh pelaku upacara. Kadang-kadang tujuannya adalah untuk mencegah perubahan yang tidak diinginkan. Tema Upacara batimbang merupakan kelahiran kembali menandai masuknya seseorang ke dalam cara keberadaan yang baru, yang suci. Pada upacara batimbang urang Banjar menyucikan situasi-situasi kritis dan marginal dalam hidup individu dan kolektif. Upacara diselenggarakan untuk mencegah bahayabahaya yang tersembunyi.

Waktu pelaksanaan upacara adat batimbang tidak ditentukan secara tegas kapan harus melaksanakannya. Menurut Ibu Aminah, mengenai waktu bisa kapan saja, batimbang bayi yang lahir pada bulan safar yang dilakukan urang banjar biasanya dilakukan memasuki bulan selanjutnya, pada umumnya dilakukan sebelum acara akikah dan tasmiyah anak. Sebaiknya dilakukan dalam waktu tidak terlalu lama dari waktu kelahiran anak tersebut. Tetapi boleh juga dilakukan kapan-kapan saja, yang penting melaksanakan upacara adat batimbang sekali seumur hidup anak tersebut. kebanyakan orang melaksanakan upacara batimbang setelah hari Jumat shalat ashar. Waktu ini dipilih karena, hari Jumat hari yang baik, setelah shalat ashar merupakan waktu yang nyaman dan untuk berkumpul sehabis melaksanakan kegiatan sehari-hari. Tetapi boleh saja dilakukan pada hari lain dan pada jam berapa saja. ${ }^{5}$ Adapun tempat

${ }^{5}$ Wawancara dengan Ibu Khadijah (40 th), 12 Oktober 2016. Kecamatan Tungkal Ilir 
pelaksanaan upacara adat batimbang anak kelahiran bulan Safar ini harus dilaksanakan di rumah atau kediaman keluarga yang mempunyai anak dengan kategori ini. ${ }^{6}$

Peralatan dan bahan-bahan yang diperlukan dalam penyelenggaraan upacara adat batimbang antara lain:

1. Ayunan;

Ayunan dibuat dari tapih bahalai atau kain sarung wanita yang pada ujungnya diikat dengan tali atau pengait. Ayunan terdiri dari tiga lapis kain. Ayunan ini biasanya digantungkan pada penyangga ruangan tengah rumah. Pada tali ayunan tersebut diikatkan tulisan surah Yasin, daun jaringau, kacang parang, dan banglai, dengan tujuan sebagai penangkal jin (makhluk halus) atau penyakit yang dapat mengganggu bayi. Ayunan berjumlah dua buah, pada waktu upacara batimbang satu ayunan untuk meletakkan anak yang akan ditimbang, sedangkan ayunan yang satu lagi untuk meletakkan al-Quran dan piduduk (syarat perlengkapan upacara terdiri dari bahan-bahan mentah yang akan dimasak setelah acara batimbang selesai. Di antara ayunan yang diduduki atau anak yang akan ditimbang dengan ayunan yang berisi al-Quran dan Pipiduk (bahan-bahan makanan mentah), dihubungkan oleh sebatang tebu.

2. Tebu Kuning;

Tebu Kuning beruas panjang, pada pelaksanaan upacara batimbang tebu digunakan sebagai dacin ${ }^{7}$ atau balok atau tiang tempat menggantung ayunan yang berfungsi sebagai anak timbangan. Di ujung tebu disangkutkan seutas tali untuk mengangkat ayunan yang berisi alQuran dan piduduk maupun ayunan yang menjadi tempat duduk bayi atau anak yang akan ditimbang

3. Piduduk;

Piduduk adalah syarat upacara yang berupa bahan-bahan mentah. Bahan utama yang termasuk dalam piduduk yaitu pulut atau beras ketan, selain beras ketan, piduduk dilengkapi dangan sedikit gula merah, sedikit garam (untuk anak laki-laki) atau sedikit garam ditambah dengan minyak goreng (untuk anak perempuan). Biasanya bahan-bahan makanan yang menjadi perlengkapan piduduk setelah upacara batimbang selesai

6 Wawancara dengan Ibu Aminah (66 th), 12 Oktober 2016. Kecamatan Tungkal Ilir.

${ }^{7}$ Dacin adalah alat penimbang berupa tongkat yang diberi skala serta anak timbangan dan tempat untuk meletakkan barang. 
dilaksanakan akan di masak dan digunakan sebagai suguhan pada orangorang yang hadir pada acara tersebut. Piduduk disiapkan dua, satu untuk keperluan upacara dan yang akan diberikan kepada bidan kampung yang memimpin upacara batimbang sebagai hadiah atau sedekah.

4. Al-Quran;

Mushaf al-Quran pada pelaksanaan upacara batimbang diletakkan dalam ayunan sarung untuk mengimbangi berat badan bayi atau anak.

5. Air Yasin/air doa

Air yang sudah bacakan surah Yasin disertai doa selamat dan tolak bala yang dimintakan dari Tuan guru/ustadz. Air Yasin bisa juga dimintakan atau disediakan oleh Bidang Kampung.

Upacara adat batimbang biasa dipimpin oleh sesepuh perempuan (tatuha babinian) keluarga yang melaksanakan misalnya nenek sang bayi, atau orang yang paham akan tata cara laksana upacara adat batimbang seperti bidan kampung. ${ }^{8}$ Orang tua bayi, baik ayah maupun ibu harus hadir dan tidak boleh diwakilkan. Setelah prosesi upacara batimbang sudah selesai dilaksanakan, tahapan selanjutnya ditutup dengan pembacaan surah Yasin, doa selamat dan tola bala dipimpin oleh seorang tuan guru/ ustadz (pemuka agama). ${ }^{9}$

\section{Prosesi Pelaksanaan Upacara Adat Batimbang}

Dalam masyarakat Banjar yang menetap di Tungkal Ilir batimbang diejawantahkan dalam kegiatan spiritual nyalamat. Kata ini dalam bahasa Indonesia diartikan dengan selamat. Upacara ini dilaksanakan dengan tujuan untuk mencari keselamatan dalam hidup dan menjauhkan malapetaka, karena sifatnya berupa ritual keagamaan, maka keselamatan yang hendak didapatkan adalah keselamatan baik secara lahir maupun batin. Pembukaan acara dimulai dengan puji-pujian kepada Allah SWT dan kepada Nabi Muhammad SAW dan di tutup dengan membaca doa selamat dan doa tolak bala. Nyalamat atau upacara selamatan merupakan konsep universal yang di setiap tempat ada dengan nama yang berbeda. Nyalamat juga suatu bentuk acara syukuran dengan mengundang para kerabat dan tetangga. Dalam praktikya, nyalamat merupakan sebuah acara perjamuan makan dan berkumpul, dengan tujuan meminta kelancaran

beranak.

${ }^{8}$ Sebutan atau istilah yang digunakan suku Banjar untuk menyebut dukun Tungkal Ilir

9 Wawancara dengan ibu Arbaiyyah (60 th), 12Oktober 2016. Kecamatan 
atas segala sesuatu yang dihajatkan dari sang penyelenggara yang mengundang orang-orang sekitar untuk datang yang dipimpin oleh orang yang dituakan atau orang yang memiliki keahlian dibidang tersebut.

Selain nyalamat, urang Banjar juga memakai istilah lain untuk acara perjamuan makan yang disebut arub atau aruban. Arub atau aruban diadakan sebagai upacara yang wajib dan mengikat secara turun-temurun seperti upacara perkawinan, upacara setelah kematian dan upacara besar lainya. Sedangkan nyalamat diadakan sesuai dengan keperluan. Tujuan aruhan mengumpulkan orang sama dengan tujuan nyalamat untuk melaksanakan upacara-upacara tertentu dengan aspek-aspek religi terkandung di dalamnya. Perbedaaan antara aruban dan nyalamat terdapat jumlah usaha pengumpulan orang. Aruban orang yang diundang lebih banyak. Sedangkan nyalamat jumlah orang yang berkumpul atau orang yang diundang lebih sedikit. Aruban dilaksanakan dalam wujud yang lebih besar atau meriah, sedangkan nyalamat wujudnya lebih sederhana.

Seiring dengan perkembangan zaman yang semakin mengglobal, upacara batimbang mengalami perkembangan dan perubahan-perubahan baik dari sisi substansi maupun fungsi. Hal ini disebabkan adanya kecenderungan pola pikir yang semakin berorientasi praktis, perubahan pandangan, dan keyakinan, serta perkembangan ilmu pengetahuan dan teknologi. Upacara batimbang pada masa sekarang ini cenderung mengalami penyederhanaan baik sarana maupun prosesinya.

Prosesi upacara batimbang anak kelahiran bulan Safar mempunyai beberapa tahapan, yakni tahap persiapan, penimbangan bayi dengan alQuran dan piduduk, dan tapung tawar.

1. Persiapan

Acara batimbang dimulai dengan mempersiapkan semua keperluan atau perlengkapan. Setelah semua peralatan dan bahan tersedia, maka prosesi upacara adat batimbang sudah siap untuk dilakukan. Pertama-tama, ayunan digantungkan di tempat upacara, yakni di ruangan bagian tengah rumah yang dijadikan tempat ritual, tebu panjang sebagai dacing di gantung di tengah. Masing-masing ujung tebu sisinya diletakkan ayunan sarung. Ayunan yang satu diisi beras pulut/ketan beserta bahan-bahan yang menjadi syarat piduduk dan mushaf al-Quran dan ayunan yang satu lagi untuk meletakkan bayi yang akan ditimbang. Upacara didahului dengan shalawat kepada Nabi Muhammad SAW dan aba-aba sesepuh keluarga atau bidang kampung yang memimpin jalannya upacara 
Makna Upacara Batimbang dalam Tradisi Masyarakat Suku Banjar Kuala Tungkal, Provinsi Jambi

penimbangan. Setiap tahapan upacara batimbang selalu diiringi shalawat nabi dan basmallah.

2. Batimbang atau penimbangan

Pada prosesi upacara batimbang dilakukan tiga kali penimbangan. Timbangan yang pertama bayi ditimbang dengan mushaf al-Quran, bayi dimasukan ke ayunan sarung. Posisi bayi yang ditimbang dalam ayunan ada yang dibaringkan dan ada pula posisi duduk dengan istilah dipukung. Ayunan sarung yang satu lagi diisi al-Quran. Setelah seimbang, sang bayi dikeluarkan. Kemudian dilanjutkan timbangan kedua, bayi ditimbang beras dengan pulut atau ketan dan bahan-bahan yang menjadi piduduk. Berat tubuh bayi pun diseimbangkan dengan ayunan sarung yang berisi pulut atau ketan dan bahan-bahan yang menjadi piduduk kalau kurang imbang, beras pulut atau ketan ditambah lagi sampai benar-benar seimbang. Setelah selesai timbangan yang kedua bayi dikeluarkan kembali dari ayunan. Setelah itu bayi dimasukkan kembali ke dalam ayunan untuk timbangan yang ketiga. Pada timbangan yang ketiga bayi ditimbang dengan ketan hingga ketan yang tersedia habis.

3. Tapung Tawar

Setelah selesai posesi penimbangan dilakukan, dilanjutkan dengan acara tapung tawar. Tapung Tawar adalah tahap prosesi dalam memberi berkat dari acara tersebut dengan malapai (mengusap) kening dan kepala anak serta mencipratinya dengan air khusus yang sudah dibacakan surah Yâsin serta doa selamat dan tolak bala yang biasanya disebut dengan air "tatungkal" yang terdiri dari campuran air, minyak wangi, dan rempah-rempah yang beraroma wangi dan air tersebut terlebih dahulu diberikan wewangian seperti jeruk purut dan sebagainya. Dalam upacara ini, penapung tawar menggunakan seikat dadaunan tertentu untuk memercikkan air terhadap orang yang ditepung tawari, disertai doa-doa untuk anak tersebut.

4. Penutupan dengan nyalamat

Setelah selesai tapung tawar para kerabat yang datang membaca surah Yâsin, doa selamat dan doa tolak bala yang dipimpin oleh seorang tuan guru/ ustad (pemuka agama) agar segala bala, musibah serta hal-hal yang dikhawatirakan tidak menimpa anak yang ditimbang dan keluarganya. Nyalamat merupakan perwujudan dari doa, doa merupakan kunci kunci keselamatan, tolak bala dan bencana. Dengan doa atas izin Allah SWT. akan mampu menolak kemungkinan-kemungkinan musibah dan bencana yang bakal terjadi, merubah takdir yang sudah terjadi 
maupun yg belum, menjamin dan mempercepat terwujudnya doa-doa dan keinginan dari orang yang mempunyai hajat dan mengantarkan anak yang ditimbang tersebut kepada kesuksesan, kebahagiaan, dan keselamatan dunia akhirat. Upacara batimbang merupakan perlambang antara harapan dan rasa syukur. Inti upacara batimbang sebenarnya adalah doa memohon perlindungan dari ancaman bahaya seperti bencana, juga doa memohon pengampunan, dosa-dosa dan kesalahan yang telah dilakukan yang dapat menyebabkan bencana.

5. Penyerahan Piduduk

Acara selanjutnya ialah menyerahkan piduduk kepada bidan. Pada waktu berlangsungnya upacara batimbang, piduduk diletak di bawah timbangan ayunan. Setelah upacara batimbang selesai, piduduk akan diserahkan kepada bidan kampung atau orang yang memimpin upacara sebagai "sedekah" atau "hadiah" atas tenaganya (jerih payah) membantu jalannya acaranya, bukan sebagai upah. Kealfaan memberikan piduduk kepada yang berhak menyebabkan segala kegiatan yang dilakukan tidak ada artinya.

6. Makan bersama

Setelah ritual batimbang selasai, beras pulut atau ketan dan bahan piduduk tadi yang dipakai untuk menimbang bayi atau anak kelahiran bulan Safar dimasak dan dibagikan pada kerabat dan keluarga untuk dimakan bersama-sama di tempat pelaksanaan upacara batimbang dan dibawa pulang. Sebagai sebuah ritual, seperti yang sudah dipaparkan sebelumnya, makan bersama merupakan kegiatan makan seremonial agar memperoleh berkah. Makanan-makanan yang terdapat dalam upacara ini memiliki simbol-simbol khusus sesuai dengan tujuan dari upacara tersebut memohon berkat untuk apa, karena upacara batimbang berkaitan kelahiran, maka makanan yang disajikan adalah yang makanan atau benda-benda yang membawa simbol tentang hidup.

\section{Fungsi dan Tujuan Upacara Ritual Batimbang}

Upacara batimbang adalah tradisi atau kebiasaan turun temurun. Setiap tradisi yang dilakukan oleh suatu masyarakat biasanya memiliki makna, fungsi dan manfaat yang dirasakan oleh masyarakat pelaku. Tradisi tersebut juga mendorong masyarakat semakin melakukan dan mentaati tatanan sosial tertentu. Tradisi-tradisi ini memberikan motivasi dan nilai-nilai yan paling dalam. Untuk itulah upacara batimbang dilaksanakan dengan tujuan-tujuan tertentu. Berikut ini tujuan-tujuan dari upacara batimbang. 
Makna Upacara Batimbang dalam Tradisi Masyarakat Suku Banjar Kuala Tungkal, Provinsi Jambi

\section{Tolak Bala}

Tujuan yang ingin dicapai dalam pelaksanaan upacara adat batimbang adalah agar anak selamat dari segala bala' serta musibah yang dipercaya akan datang kepada anak tersebut, yang juga berdampak pada keluarganya, menghindari dari kesulitan atau kendala serta agar anak kelak bisa melalui segala kesulitan yang dihadapidalam hidupnya.

2. Pemulihan dan Menghilangkan Tabiat Buruk

Upacara Batimbang dilakukan atau dikenakan pada bayi atau anak yang lahir di bulan Safar karena menurut keyakinan tradisional orang Banjar jika seseorang dilahirkan di bulan Safar, orang itu akan memiliki tabiat yang buruk. Seperti yang diutarakan Ibu Najemah, kami melakukan upacara batimbang yang ditimbang al-Quran di samping anakku dengan harapan agar bila besar senang membaca al-Quran dan menuruti perintah Allah dan Rasulnya yang ada di dalam al-Quran. Anak saya ditimbang dengan ketan dengan harapan agar tidak keras kepala, nakal dan susah diatur, seperti tekstur ketan yang lembut dan lunak, agar anak saya menurut dan ingat dengan perintah dan ajaran orang tuanya seperti ketan yang lengket. Dari segi kelengketan ketan tujuannya agar apa diajarkan orang tua dan perintah Allah dan Rasul lengket di dalam jiwa dan kelakuannyanya. ${ }^{10}$

3. Penangkal Gangguan Mahkluk Gaib

Tujuan dan maksud dilaksanakan upacara batimbang ini menurut Ibu Desi untuk menangkal atau menetralisir kekuatan gaib yang akan membahayakan. Pada bulan ini, segala penyakit, racun, dan hal-hal yang berbau magis memiliki kekuatan yang lebih dibanding pada bulan lainnya. Ia menganggap upacara batimbang, biar anak yang dilahirkan tidak panasan (gelisah, cengeng dan rewel) menjadi dinginan (tenang) dan juga tidak sial.

4. Menghilangkan Kekhawatiran

Tujuan batimbang yang lain adalah untuk menghilangkan segala kekhawatiran dari orang lain kepada keluarga tersebut, karena bila terdapat salah satu keluarga tidak melaksanakannya, maka akan timbul rasa was-was atau takut kalau akan terjadi "apa-apa" pada anak tersebut. Penyelenggaraan upacara ini dilatarbelakangi pula dengan keinginan untuk mendapatkan ketenangan hidupdan harapan, si anak kelak bisa melalui segala kesulitan yang dihadapinya kelak. Bila seseorang menderita

${ }^{10}$ Wawancara dengan Ibu Desi (38th), 13 September 2016, Kecamatan Tungkal Ilir. 
karena berbagai alasan, seperti musibah kecelakaan, sakit, berbuat salah dan seterusnya, dikatakan orang itu mengalami waktu jelek atau naas. Setiap orang akan selalu berusaha membuang sial, menghindari waktu naas, dan berusaha hidup dalam keselamatan dan kebahagiaan. Upacara batimbang ini semua dilakukan guna memperoleh keselamatan, karena semua yang terjadi di dunia ini tidak dapat ditebak untuk itu mereka melakukan kegiatan ini agar memperoleh keselamatan.

5. Menjauhkan dari hal-hal yang tidak baik.

Tujuan yang lain, yakni menjauhkan segala hal-hal yang tidak baik. Di samping itu, upacara adat batimbang merupakan salah satu dari acara nyalamat (acara doa selamat) yang dilaksanakan untuk menjaga sang anak dari segala hal yang bersifat kurang baik. Urang Banjar di Tungkal Ilir juga mengenal dan melaksanakan banyak acara nyalamat yang berkaitan dengan upacara siklus hidup dan upacara adat lainnya seperti pindah rumah baru dan lain sebagainya dengan tujuan memohon kepada Allah untuk diberi keselamatan. Nyalamat atau upacara doa selamat pada upacara batimbang menimbulkan efek psikologi dalam bentuk keseimbangan emosional dan mereka meyakini bakal selamat, tidak terkena musibah atau tertimpa malapetaka setelah mereka melakukan kegiatan ini.

6. Menjalankan Tradisi Nenek Moyang

Batimbang menurut Suhairi merupakan tradisi keluarga yang sudah turun temurun khusus untuk anak-anak yang lahir di bulan Safar saja. Suhairi menyatakan bahwa upacara adat batimbang ini harus tetap dilaksanakan, di samping demi menjaga anak dari bala', juga untuk melestarikan budaya warisan nenek moyang kita. Dari dulu sampai sekarang orang-orang percaya terhadap apa yang diajarkan, dianjurkan dan diutarakan oleh para tatuha (sesepuh), karena menurut kami (urang Banjar) petuah atau ajaran para tatuba mempunyai makna sangat dalam, sehingga dengan kelangsungan upacara tersebut akan mewujudkan keselamatan dan keteraturan bagi kehidupan lahir dan batin anak tersebut dan keluarganya. ${ }^{11}$

Walaupun dampak globalisasi informasi dan komunikasi sudah masuk dalam kehidupan masyarakat Banjar di Tungkal Ilir, ternyata sebagian besar masyarakat Banjar masih mempertahankan nilai-nilai tradisional. Hal tersebut terlihat dengan adanya pelaksanaan berbagai

${ }^{11}$ Wawancara dengan Bapak Suhairi (55th), 21 Oktober 2016, Kecamatan Tungkal Ilir. 
macam upacara, misalnya kematian, pendirian rumah, dan lain-lain, termasuk upacara batimbang. Sebagian masyarakat tradisional ini takut meninggalkan kebiasaan yang telah mengakar dalam segi-segi kehidupan mereka, dan masih setia mempertahankan tradisi peninggalan leluhurnya. Dengan tujuan untuk mempertahankan adat, sebagian orang ada yang berpendapat apabila tidak dilakukan takut terjadi hal-hal yang mungkin tidak diinginkan, dan berharap akan ada berkah apabila melaksanakannya.

\section{Upacara Batimbang sebagai Tindakan Simbolik}

Manusia adalah "animal symbolicum”, sebagai suatu ciri yang khas dan manusiawi. Simbol merupakan salah satu bagian dari aspek kebudayaan yang merupakan media pemikiran manusia yang berasal dari suatu ide, gagasan, norma, dan peraturan. Simbol dapat diaplikasikan dalam setiap segi kehidupan manusia sebagai suatu aktivitas berpola dari manusia dalam kehidupan bermasyarakat. ${ }^{12}$

Apakah sebenarnya simbol batimbang itu? Simbol batimbang adalah simbol-simbol batimbang yang terdapat di dalam upacara batimbang. Dalam pengertian itulah simbol-simbol batimbang sangat berkaitan erat dengan kehidupan urang Banjar, suatu kehidupan yang mengungkapkan perilaku dan perasaan manusianya melalui upacara adat. Sebagai salah satu bentuk upacara lingkar hidup adat banjar, batimbang memiliki serangkaian inti upacara di dalamnya.

Batimbang yang dilakukan oleh urang Banjar sangat erat dengan siklus kehidupan manusia, siklus hidup mengandung pengertian yang ditujukan kepada siklus dalam lingkaran perjalanan hidup-kehidupan manusia secara berputar (berproses) baik sebagai individu atau masyarakat pendukung budaya kelompok etnik tertentu. Pengertian Siklus kehidupan adalah dikaitkan dengan upacara-upacara ritual kehidupan manusia secara individual maupun kelompok masyarakat telah diikat oleh religi dan menjadi tradisi-budaya, sehingga tidak bisa dipisahkan dari aspek kehidupan manusia dan menjadi kepribadian suku etnik tertentu.

Siklus kehidupan tersebut dianggap sakral, oleh karena itu perlu ditandai dengan upacara tertentu yang sarat dengan perilaku dan benda-

${ }^{12}$ Ernest Cassirer, An Essay on Man (Fredericksburg: Book Crafters, 1979), 315. 
benda simbolis, sehingga dapat mendukung atau melestarikan warisan leluhur yang dianggap sakral dan pandangan hidup manusianya. Dalam hal ini, urang banjar adalah manusia yang memiliki sejumlah pengetahuan tentang apa yang diyakininya dan keyakinan itu dianggapnya sebagai sebagai pandangan hidup yang kemudian yang dijadikan sebagai pola atau "petunjuk jalan" dalam kehidupan sehari-hari ataupun kehidupan religiusnya.

Manusia adalah makhluk budaya dan bersimbol, simbol itu terefleksi dengan perilaku-perilaku masyarakat, kemudian membentuk sistem nilai yang terkandung dalam adat istiadat suatu budaya tertentu. Upacara batimbang merupakan tindakan simbolis dan perwujudan dari makna religius dan sarana untuk mengungkapkan sikap-sikap religius masyarakat Banjar. Simbol itu sendiri menjadi pokok ketegangan dan dilema dalam agama. Bila seorang beragama mesti mempertahankan pengalaman asli religiusnya dengan relasinya yang melampaui pengalaman biasa dengan yang ilahi, pada upacara batimbang harus mengungkapkan ini lewat bentuk-bentuk simbolis yang bersifat empiris dan menjadi bagian dari wilayah profan.

Upacara atau ritus berhubungan dengan kekuatan ${ }^{13}$ supranatural dan kesakralan sesuatu. Karena itu istilah ritus atau ritual dipahami sebagai upacara keagamaan yang berbeda sama sekali dengan yang natural, profan, dan aktivitas ekonomis, rasional sehari-hari. Ritual dilakukan sebagai salah satu sarana mencari keselamatan dan bukti nyata tentang keyakinan yang dimiliki oleh kelompok atau anggota masyarakat tentang adanya kekuatan yang maha dahsyat di luar manusia.

Melalui kegiatan ritual, urang Banjar ingin mengetahui serta ingin menyatakan keagamaan itu sendiri, berupaya menyatukan diri dengan sesuatu hal yang berarti di balik kenyataan fisik, bahkan suatu hal yang transenden. Namun manusia yang terbatas tidak mampu mencapainya, karena itulah urang Banjar menggunakan simbol sebagai media budaya, itulah akar simbolisme dalam budaya Banjar. Keterbatasan kekuatan manusia menciptakan simbol sebagai usaha untuk mendekatkan diri kepada Tuhan. Simbol-simbol ini digunakan untuk memberi kemungkinan "suatu perpanjangan dari penampakan yang ilahi. ${ }^{14}$

\footnotetext{
${ }^{13}$ Agus Bustanuddin, Agama dalam Kehidupan Manusia: Pengantar AntropologiAgama (Jakarta: Rajawali Press, 2006), 97.

${ }^{14}$ Mircea Eliade, Patterns in Comparative Religion (London; New York: Sheed \& Ward, 1958), 448.
} 
Tahapan-tahapan dalam upacara batimbang menandai suatu perilaku formal yang tampaknya bukan ditanamkan oleh kepentingan atau menurut makna-makna rasional. Perilaku ritual bersifat simbolis, yaitu menyatakan sesuatu tentang keadaan persoalan-persoalan tersebut, tetapi tidak harus mempunyai implikasi tindakan. Si pelaku tidak harus mempunyai maksud menggantikan keadaan itu. Ritual-ritual peringatan, seperti halnya di atas, dikaitkan dengan model-model mitologi dan menghadirkan suatu karakter "sinkero-diakronis", dalam arti bahwa ritualritual tersebut menciptakan suatu ikatan antara yang rutin dengan gambaran-gambaran atau simbol-simbol di luar waktu. ${ }^{15}$

Upacara batimbang anak kelahiran bulan Safar berarti ada waktu baik dan ada waktu jelek bagi setiap orang. Bila seseorang menderita karena berbagai alasan, seperti musibah kecelakaan, sakit, berbuat salah dan seterusnya, dikatakan orang itu mengalami waktu jelek atau naas. Setiap orang akan selalu berusaha membuang sial, menghindari waktu naas, dan berusaha hidup dalam keselamatan dan kebahagiaan.

\section{Upacara Betimbang sebagai Ritus Inisiasi}

Pada hakikatnya upacara batimbang adalah upacara inisiasi atau peralihan sebagai sarana untuk menghilangkan petaka, bala dan musibah. Upacara batimbang merupakan simbol upacara sebagai pernyataan tanda pembersihan diri, baik fisik maupun jiwa. Ini semua dilakukan guna memperoleh keselamatan, karena semua yang terjadi di dunia ini tidak dapat ditebak, maka mereka melakukan kegiatan ini guna agar memperoleh keselamatan. Ia harus melakukan doa-doa dan puji-pujian; mampu melakukan peribadatan kepada Tuhan yang ia sembah; bersedia melakukan tindakan-tindakan yang menunjukkan perhatian kepada orang lain dengan cara berbuat baik, sedekah, dan lain sebagainya.

Agama merupakan suatu upaya yang digunakan untuk menyembah ilahi yang dipercayai dapat memberikan keselamatan serta kesejahteraan hidup dan kehidupan kepada manusia, yang dilakukan dengan dengan berbagai ritus secara pribadi dan bersama. Agama, budaya dan masyarakat jelas tidak akan berdiri sendiri, ketiganya memiliki hubungan yang sangat erat dalam dialektikanya; selaras dalam menciptakan ataupun kemudian saling menegasikan.

${ }^{15}$ Claude Lévi-Strauss, La pensée sawvage (Paris: Plon, 1962). h. 121 
Selain sistem keyakinan ataupun religi yang dimiliki manusia, terdapat juga bentuk-bentuk keyakinan lain yang dimiliki oleh manusia. Bentuk-bentuk keyakinan itu direalisasikan dengan munculnya mitos. Antara mitos dan ritual, keduanya merupakan elemen yang sangat berkaitan dengan perilaku manusia dalam memahami kehidupan beragamanya khususnya dalam upacara-upacara religius. Sebenarnya ritual atau upacara-upacara tersebut ditampilkan dengan perilaku religius tertentu yang terkait dengan kehidupan beragama dan juga menandai adanya tahap peralihan dari suatu kelompok ke kelompok lain dalam masyarakat dan dari situasi ke situasi yang lain.

Mitos yang berperan sebagai peristiwa pemula dalam upacara atau ritual batimbang. Di dalam masyarakat Banjar di Kecamatan Tungkal Ilir, di mana mitos masih hidup dan maknanya merefleksikan pengalaman religiusnya. Mitos merupakan kisah yang diceritakan untuk menetapkan kepercayaan tertentu, berperan sebagai peristiwa pemula dalam upacara atau ritual punggahan. Pengalaman religius dan pemahaman akan yang religius dihadirkan dengan berbagai cara, seperti melakukan upacara dan ritual batimbang ini. Mitos dalam upacara dan ritual batimbang memuat kepercayaan di mana bulan Safar dipercaya sebagai bulan naas dan bulan penuh mara bahaya untuk setiap peristiwa yang terjadi di bulan Safar ini, terutama peristiwa kelahiran.

Mitos, dalam kaitannya dengan agama, menjadi penting bukan semata-mata karena memuat kejadian-kejadian ajaib atau peristiwaperistiwa mengenai makhluk adi kodrati, melainkan karena mitos tersebut memiliki fungsi eksistensial bagi manusia. ${ }^{16}$ B. Malinowski menekankan hal ini: "Dalam peristilahan antropologi, ini berarti bahwa mitos atau cerita-cerita suci harus dirumuskan menurut fungsinya. Mitos merupakan kisah yang diceritakan untuk menetapkan kepercayaan tertentu, berperan sebagai peritiwa pemula dalam suatu upacara atau ritus. Atau sebagai model tetap dari perilaku moral maupun religius, karenanya mitologi atau tradisi suci dari suatu masyarakat adalah kumpulan cerita yang terjalin dalam kebudayaan mereka, yang berlaku sebagai peta peraturan sosial maupun sebagai model tetap dari tingkah

${ }^{16}$ Irmayanti Meliono Budianto, Ideologi Budaya (Jakarta: Yayasan Kota Kita, 2004), 150. 
laku moral mereka. Mitos menentukan hubungan ritual antara manusia dengan penciptanya, atau dengan makhluk adi kodrati yang ada. ${ }^{17}$

Siklus kehidupan manusia lahir, menikah, dan mati dianggap sakral, oleh karena itu perlu ditandai dengan berbagai upacara. Upacaraupacara siklus kehidupan memainkan peranan penting dalam kehidupan manusia religius sebagai sarana bagi untuk bertindak religius. Upacara siklus kehidupan bersifat ritualistik. Sebuah upacara selalu melibatkan inisiasi, menurut Mircea Eliade, upacara inisiasi selalu diadakan pada setiap kali manusia menghadapi tahapan baru dalam hidupnya karena menunjukan perubahan-perubahan radikal dalam status ontologis maupun sosial. ${ }^{18}$

Upacara adat batimbang berarti ditimbang agar seimbang dan cukup untuk melepaskan anak dari hal-hal yang menimbulkan bahaya, malapetaka atau keadaan yang menyedihkan. Batimbang dapat juga berarti dipulihkan atau dikembalikan pada keadaan semula baik, tetapi juga menolak bencana yang diyakini akan menimpa pada diri seseorang dan menetralisir kekuatan gaib yang akan membahayakan. Upacara ini biasa dilakukan orang hingga sekarang sebagai suatu upacara yang diadakan sebagai sarana yang dijalankan supaya dapat terhindar dari marabahaya yang diramalkan akan menimpa diri seseorang.

Semua upacara diarahkan pada tranformasi keadaan manusia atau alam. Kadang-kadang tujuannya adalah untuk menjamin perubahan amat cepat dan menyeluruh pada keadaan akhir yang dinginkan oleh pelaku upacara. Kadang-kadang tujuan untuk mencegah perubahan yang tidak diinginkan. Kadangkala juga targetnya adalah satu aspek hakikat bukan manusia; kadang manusiawi, kadang individu, atau suatu kelompok. Perubahan yang dimaksud kadang merupakan suatu perubahan kecil, suatu koreksi yang akan memulihkan suatu perubahan kecil, suatu koreksi yang akan memulihkan keseimbanggan dan status quo, melestarikan gerakkan sistem dalam ikatan-ikatan; kadang menyangkut perubahan sistem yang radikal, tercapainya level keseimbangan baru atau, bahkan kualitas baru dalam organisasi.

\footnotetext{
${ }^{17}$ Bronislaw Malinowski, Sex, Culture, and Myth. (New York: Harcourt, Brace \& World, 1962), 305.

${ }^{18}$ Mircea Eliade, The Sacred and the Profane the Nature of Religion (New York: NY Harcourt Brace, 1959), 212.

${ }^{19}$ Mariasusai Dhavamony, Phenomenology of Religion (Rome: Gregorian University Press, 1973), 108.
} 
Upacara batimbang merupakan siklus kehidupan bagi masyarakat Banjar penganut agama Islam yang memberikan makna, ketika mereka melewati berbagai tahap kehidupan. Siklus kehidupan adalah pertemuan Islam dan budaya lokal sebagai sistem simbol dan tindakan yang memainkan peranan penting dalam meneguhkan kembali pandangan Islam, baik pada pengalaman hidup, pemikiran, dan budaya. Urang Banjar meyakini bahwa, kehidupan manusia selalu diiringi dengan masa-masa kritis, yaitu suatu masa yang penuh dengan ancaman dan bahaya. Masamasa itu adalah masa peralihan dari tingkat kehidupan yang satu ke tingkat kehidupan lainnya (dari manusia masih berupa janin sampai meninggal dunia). Karena masa-masa tersebut dianggap sebagai masa yang penuh dengan ancaman dan bahaya, maka diperlukan adanya suatu usaha untuk menetralkannya, sehingga masa-masa tersebut dapat dilalui dengan selamat. Usaha tersebut diwujudkan dalam bentuk upacara yang kemudian dikenal sebagai upacara lingkaran hidup individu yang meliputi: kehamilan, kelahiran, khitanan, perkawinan, dan kematian.

Tradisi upacara adat batimbang dilakukan sebagai suatu permohonan agar manusia diselamatkan dari gangguan dan bencana yang mengancam hidup dan kehidupannya. Melalui batimbang, manusia merasa terlindungi oleh kekuatan besar yang dipercaya sebagai kekuatan penyelamat sehingga dalam dirinya muncul hasrat untuk selalu sadar, bertobat, mendekat, bermohon, berserah diri dan semacamnya kepada kekuatan penyelamat yang dimaksud. Dalam Upacara batimbang tersebut terdapat peralatan, makanan yang akan disedekahkan, pembacaan ayat suci al-Quran, doa selamat dan doa tolak bala yang dijadikan sarana untuk menjembatani komunikasi antara manusia dengan kekuatan penyelamat yaitu Allah yang maha besar.

Penyelenggaraan upacara batimbang merupakan ungkapan rasa syukur dan terima kasih terhadap kekuatan yang dianggap maha tinggi. Selain itu upacara yang berhubungan dengan peristiwa kelahiran seorang anak di bulan Safar yang penuh bala dan kepercayaan diadakan untuk memohon keselamatan atau kesejahteraan berkenaan dengan rasa takut dan tunduk, serta timbul rasa kagum terhadap kekuatan supernaturalyang diyakini.

Mircea Eliade sudah menunjukkan makna yang lebih dalam dari ritual..$^{20}$ Menurutnya, ritualnya mengakibatkan suatu perubahan ontologis

${ }^{20}$ Mircea Eliade; Willard R Trask; Michael J Meade, Rites and symbols of initiation: the Mysteries of Birth and Rebirth (Putnam, Conn: Spring Publications, 2012), 231. 
pada manusia dan mentransformasikannya kepada situasi keberadaan yang baru, misalnya penempatan ke dalam lingkup yang kudus. Teori ritual ini dilukiskan oleh ritus inisiasi. Inisiasi tidak hanya menandai kelahiran kembali individu tapi juga membawanya ke cara berada yang lebih tinggi, yakni cara berada yang dikuduskan. Pada hakikatnya upacara batimbang adalah upacara inisiasi atau peralihan sebagai sarana untuk menghilangkan petaka, bala dan musibah. Upacara batimbang merupakan simbol upacara sebagai pernyataan tanda pembersihan diri, baik fisik maupun jiwa. Ini semua dilakukan guna memperoleh keselamatan, karena semua yang terjadi di dunia ini tidak dapat ditebak untuk itu mereka melakukan kegiatan ini guna agar memperoleh keselamatan. Upacara ini dianggap memuat pengalaman baru, yakni pengalaman akan yang ilahi. Simbol-simbol ritual inisiasi tidak hanya menunjuk pada dunia individu masyarakat dewasa, namun juga keberadaan religiusnya. Secara sosial, upacara itu menandai tanggung jawab orang dewasa; dan secara religius menampilkan tanggung jawab setiap manusia untuk melestarikan tradisi suci.

\section{Nilai Religius dalam Simbol-simbol Upacara Batimbang.}

Upacara batimbang yang dilakukan oleh masyarakat Banjar yang berada di Tungkal Ilir Kabupaten Tanjung Jabung Barat ini, jika dicermati secara saksama, maka di dalamnya mengandung makna dan nilai yang dapat dijadikan sebagai acuan dalam kehidupan bersama. Sistem nilai budaya masyarakat, menjadi pendorong atau penggerak serta pengontrol bagi tindakan-tindakanpara anggota masyarakat agar tetap berjalan sesuai dengan nilai-nilai budaya dan ajaran-ajaran agamanya. Di saat pengaruh ajaran agama demikian menguat pada sistem-sistem nilai yang ada dalam budaya masyarakat, maka sistem-sistem nilai budaya itu menjelma sebagai simbol-simbol yang maknanya bersumber pada ajaranajaran agama yangmenjadi kerangka acuannya.

Adanya simbol dan makna simbolik dari upacara batimbang ditentukan oleh makna literal, dan menembus makna literal tersebut, dan hasilnya mula-mula makna yang bersifat harifiah dan dari makna pertama tadi dibangun makna yang kedua makna refleksif, yaitu menembus makna pertama. Simbol-simbol itu diekspresikan dalam ekspresi simbolis. Ekspresi simbolis dari upacara batimbang terwujud dalam simbol-simbol tertentu, simbol-simbol tersebut merupakan manifestasi wujud tingkah laku religius seperti berikut: 
Pertama, upacara batimbang bermakna sedekah atau berbagi dengan anggota keluarga yang lain dan tetangga. Pada saat upacara berlangsung warga berkumpul dan makan bersama dan membagi-bagikan makanan dengan menu tertentu, berbuat baik kepada sesama dan beramal saleh yang diwujudkan dalam bentuk sedekah. Bersedekah atau berbagi dengan sesama merupakan ajaranyang diajarkan oleh Nabi Muhammad SAW, karena dengan bersedekah orang juga bisa menghindarkan dirinya dari bala' atau musibah. Di samping itu, dengan bersedekah masyarakatjuga bisa menjalin hubungan yang baik dengan tetangga, karena memungkinan selama hidup bermasyarakat pasti pernah terjadi pertikaian atau ketidakcocokan antara satu dengan yang lainnya. Melihat hal tersebut, maka upacara batimbang dapat dimaknai dengan bersedekah serta menjalin silaturahim dan akan tercipta kehidupan yang tentram, damai dan harmonis.

Dalam upacara tradisional selalu diadakan acara makan bersama, terutama setelah upacara selesai dilakukan. Dalam catatan Denys Lombard, tradisi makan bersama semacam itu merupakan ungkapan nyata semangat kolektif di kalangan penduduk desa dan kemungkinan besar diwarisi dari zaman kuno ketika kelompok harus bersatu mempertahankan kesatuannya dan untuk membela diri terhadap keganasan hutan rimba. Dalam konteks upacara tradisional sekarang ini, tentunya, makan bersama dilakukan dalam rangka menggalang kebersamaan untukmenangkalgangguanatau bencana.

Meskipun upacara tradisional seperti upacara batimbang ini selalu dikaitkan dengan praktik-praktik keagamaan, bentuk pengetahuan tradisional ini tidak memiliki dogma-dogma yang ketat seperti agama. Upacara tradisional merupakan bentuk atau struktur yang memiliki ciri dan penampakan yang berkaitan satu sama lain. Banyak kegiatan di dalamnya yang tidak berkaitan dengan hal-hal yang diusung agama, meskipun sebagian kegiatan yang dipertontonkan sangat bernuansa agama. Tata cara di dalamnya tidak seketat tata cara yang terdapat dalam agama. $^{21}$

Kedua, batimbang sebagai warisan nenek moyang. Batimbang anak kelahiran bulan Safar merupakan tradisi yang sejak lama dilaksanakan oleh orang Banjar, khususnya masyarakat banjar di Tungkal Ilir. Karena

${ }^{21}$ Rappaport. "Ritual" dalam Richard Bauman, ed., Folklore, cultural performances, and popular entertainments: a communications-centered handbook (New York: Oxford University Press, 1992), 250. 
batimbang ini merupakan warisan nenek moyang serta tradisi maka upacara ini sudah melekat dalam diri setiap warga Banjar di Tungkal Ilir. Pelestarian budaya ini bisa dilihat dengan perspektif teori tindakan sosial tradisional, yaitu tindakansosial yang disorong dan berorientasi pada tradisi masa lampau. Teori tindakan adalah teori yang mengacu pada tindakan yang selalu mengerjakan sesuatu sehingga sesuatu itu terjadi di dunia ini. Di dalam teori tindakan terdapat motivasi dan kausalitas, serta intervensi tindakan di dalam dunia.

Hingga saat ini upacara batimbang masih hidup, terjaga, terpelihara, dan dimanfaatkan oleh para pewarisnya. Bentuk pusaka budaya ini senyatanya memiliki dampak positif bagi kehidupan pelaku dan pesertanya, terutama yang terkait dengan kerukunan dan kedamaian hidup. Upacara batimbang bukan hanya merupakan sarana komunikasi yang produktif antara para pewarisnya dengan kekuatan yang dipercaya dapat melindungi dan memberi kesejahteraan lahir batin, tetapi juga dengan sesama pewarisnya, baik pewaris aktif maupun pasif.

\section{Makna Perlengkapan dan Makanan dalam Upacara Batimbang}

Dalam upacara batimbang yang penuh dengan simbol, hadirnya makanan dan benda tertentu dalam suatu ritual tidak bisa sembarangan. Setiap makanan dan benda tertentu memiliki makna dan fungsinya sendiri. Tentu saja, dalam hal ini seringkali bentuk, rasa, dan warna mempengaruhi makna makanan dan benda tersebut. Perlengkapan, makanan dan bahan makanan yang dipilih adalah bahan makanan yang memiliki makna. Makanan memiliki makna-makna lain yang tersirat di dalamnya. Ini bisa dilihat dari tekstur dan rasa makanannya, hingga keberadaannya di dalam suatu ritual dan upacara. Rangkaian makanan dan perlengkapan yang ditemui dalam upacara batimbang, yaitu:

1. Timbangan Ayunan

Betimbang artinya ditimbang, maka perlengkapan utama dalam upacara batimbang anak kelahiran bulan Safar ini adalah timbangan yang dibuat dari dua ayunan sarung yang dihubungkan dengan sebatang tebu. Tebu berfungsi sebagai dacin dan dua buah ayunan sarung sebagai anak timbangan. Sesuatu itu ditimbang agar seimbang, tidak kurang dan tidak lebih, untuk menjadi cukup, suatu menjadi tidak seimbang karena ada peristiwa atau suatu keadaan tertentu.

Kondisi anak dalam terganggu keseimbangannya karena dilahirkan di bulan Safar, kerena Safar merupakan dianggap bulan tidak 
baik, dapat menyebabkan bencana, mempunyai pengaruh buruk terhadap perilaku dan watak seseorang yang lahir pada bulan tersebut. segala penyakit, racun, dan hal-hal yang berbau magis memiliki kekuatan yang lebih dibanding pada bulan lainnya. Timbangan pada upacara batimbang sebagai simbol untuk mengembalikan atau memulihkan keseimbangan atau keadaan semula yang baik. Upacara batimbang dilaksanakan untuk memulihkan keadaan dan melepaskan anak yang lahir di bulan Safar dari hal-hal yang menimbulkan bahaya, malapetaka atau keadaan yang menyedihkan

2. Al-Quran

Al-Quran adalah Kalam Allah SWT yang merupakan mu'jizat yang diturunkan (diwahyukan) kepada Nabi Muhammad saw. Al-Quran merupakan pedoman dan tuntunan hidup bagi umat Islam. Oleh karena manusia religius islami harus hidup seturut al-Quran dan Hadis Nabi. Yang suci dinyatakan dan kondisi mutlak bagi keselamatan. Upacara batimbang sebagai ritus inisiasi, tema pokok dari semua ritus inisiasi arti religiusnya sangat mendalam. Secara lebih mendalam lagi, ritus inisiasi menghasilkan perubahan eksistensial yang mendasar dalam hidup individual, yaitu suatu level keberadaan yang suci.

Manusia religius memperlihatkan orientasi kehidupan, pengandaian-pengandaian dan cara-cara untuk menafsirkan eksistensi, suatu pandangan dunia yang membentuk pengertian manusia tentang dirinya dan tempat-tempatnya dalam kosmos yaitu manusia religius menempatkan diri bawah kehendak-Nya, tunduk kepada-Nya, peraturan yang ditetapkan-Nya dalam Quran dan Hadis. Ketaatan kepada perintah Allah itu sendiri disebut keshalehan, merupakan jalan keselamatan bagi muslim dengan mengikuti perintah-perintah Allah dan teladan Rasul, serta mentaati hukum.upacara betimbang adalah upacara inisiasi atau peralihan sebagai sarana untuk menghilangkan petaka, bala dan musibah dan pembersihan dari dosa-dosa yang dapat mendatangkan petaka. Gagasan dosa dalam al-Qur'an adalah perlawanan terhadap perintahperintah dan keputusan-keputusan Ilahi.

Upacara batimbang merupakan pengungkapan makna budaya "yang profan" (profane) yang berbicara tentang ketetapan "yang sakral" (sacred). Menurut Mercia Eliade, pada dasarnya agama adalah pertemuan manusia dengan Yang Suci. Manusia religius menjadi sadar terhadap keberadaan yang Suci, karena ia memanifestasikan dirinya dan menunjukkan dirinya sebagai sesuatu yang berbeda secara menyeluruh 
dari yang profan. Kekuatan sakral berarti realitas dan pada saat yang sama keabadian dan efektivitas tindakan (effectivity of act). Bahwa yang sakral dan profan adalah dua pola kehidupan di dunia, dua jalan mengada yang ditempuh oleh manusia. Sifat-sifat tertentu dari kehidupan di dunia yang dapat menjadi sakral mendeskripsikan tentang modalitas yang sakral dan situasi manusia dalam dunia yang dibebani nilai-nilai religius. ${ }^{22}$

Manusia mengalami dan merasakan diri sebagai makhluk. Manusia merasa tak berdaya, merasa hampa, tak berharga dalam berhadapan dengan maha keagungan, yang mengatasi semua makhluk. Manusia memandang dirinya berhadapan dengan kekuasaan yang mengatasi semua yang ada. Rudolp Otto menyebut pengalaman dan kesadaran religius terhadap kekuatan yang maha besar sebagai numinos atau mysterium tremendum et fascinans. Dalam analisis Otto tentang pengalaman yang religius adalah numinus sebagai ciri misterius. Artinya, pengalaman religius tidak dapat sepenuhnya ditangkap unsur rasional belaka. Secara praktis, fakta ini mendapatkan tekanan dalam setiap agama. Yang Ilahi tidak dapat sepenuhnya dimengerti akal manusia; tidak dapat diungkap secara sempurna dengan cara-cara atau kata-kata manusia. Yang ilahi disebut 'Misteri' tak dapat diterangkan, 'Yang lain sama sekali', 'Yang melebihi. Karena pengalaman akan yang Ilahi adalah pengalaman manusia, pengalaman itu menemukan perwujudannya dalam simbol-simbol lingkungan profan, dengan mana yang ilahi dicapai. ${ }^{23}$

Upacara batimbang menyampaikan arti dan makna religius. Menurut Mercia Eliade, simbol-simbol religius, muncul dari kebutuhan manusia untuk hidup dalam suatu dunia yang ideal. Maka dapat disimpulkan, bahwa nilai-nilai religius bisa berlaku sebagai andalan bagi kemantapan orientasi manusia dan perilakunya. Bagi seseorang yang beragama, agama yang dianutnya cukup memberikan tuntunan perilaku sebab sebagai suatu sumber keyakinan atau keimanan, agama secara keseluruhan dan keutuhan merupakan cara pandang bagi penganutnya mengenai manusia dan dunianya maupun peri kehidupanya.

3. Tebu

Pohon tebu itu rasanya manis dari akar sampai dengan pucuknya. Walaupun sampai ke pucuk manisnya berkurang yang penting rasa manis tetap ada, tebu itu dapat hidup dalam segala iklim dari pantai sampai ke

22Lihat Mircea Eliade, The Sacred and the Profane the Nature of Religion, 212.

${ }^{23}$ Lihat Mariasusai Dhavamony, Phenomenology of Religion, 103-110. dan Mircea Eliade, The Sacred and the Profane the Nature of Religion, 2. 
pegunungan. Sifat pohon tebu itu makin diperas makin bertambah manisnya. Tebu menyimbolkan dari upacara betimbang ini terkandung harapan agar anak-anak yang diayun selalu mendapat kebaikan dalam menempuh kehidupan.

Tebu dalam hal mistis juga dapat menangkal bala, sebagai benteng pertahanan dari makhluk-makhluk halus yang jahat. Tebu juga menyimbolkan poros dunia ini sering dilambangkan dengan tiang, tangga, pohon, dan gunung yang disebut Mercia Elide sebagai axis mundi. Melalui axis mundi ini manusia religius dapat mengadakan hubungan dengan dunia atas dan dunia bawah. Karena hubungan antara ketiga dunia itu terletak pada pusat dunia, maka dunia yang sejati selalu terdapat pada pusat dunia.

4. Bahan-bahan piduduk

Piduduk merupakan simbol-simbol yang tidak semuanya dapat diketahui artinya karena ia lebih bersifat magis. Piduduk yang diserahkan pada bidan kampung (dukun beranak) atau orang yang memimpin upacara sebagai imbalan berupa sedekah atau hadiah atas jasa-jasa (yang bersifat magis). Bukan upah, jasa-jasa tertentu akan hilang fungsinya jika untuk jasa yang diberikan dimintakan upah tertentu. Karena itu Bahanbahan piduduk ini dianggap sebagai pengganti tenaga yang terpakai. Bahan-bahan ini dianggap sebagai pengganti daging (beras) dan darah (gula). Selain itu piduduk selalu ditambahkan uang, yang senantiasa dinyatakan sebagai penambah kekurangan bila ternyata ada (oleh si penerima). Bahan-bahan makanan dan susunan bahan piduduk merupakan merupakan perlambang harapan yang ada pada upacara betimbang. Susunan bahan-bahan dalam piduduk, antara lain beras ketan/pulut, gula, garam dan minya goreng. Di antara bahan yang menjadi piduduk yang menjadi vocal pointnya adalah ketan

Beras ketan kalau sudah sudah dimasak akan menjadi nasi ketan. Nasi ketan berwarna puth, rasanya adalah tawar, tekstur nasi ketan kenyal, tidak kaku dan sifatnya lengket. Dari aspek tekstur nasi ketan yang kenyal dan lembek atau lembut mengandung harapan anak yang ditimbang dengan beras ketan dengan harapan agar tidak keras kepala, nakal dan susah diatur, seperti tekstur ketan yang lembut dan kenyal. Adapun sifat lengket dari nasi ketan tersebut menunjukkan harapan agar anak yang menjalani upacara betimbang ini menurut dan ingat dengan perintah dan ajaran orang tuanya seperti ketan yang lengket, dari segi kelengketan ketan tujuannya agar apa diajarkan orang tua dan perintah 
Allah SWT dan Rasulullah SAW, lengket di dalam jiwa dan kelakuan anak yang ditimbang. Ketan yang dimasak seperti halnya nasi dan tidak diberi apa-apa, sehingga rasa yang dihasilnya adalah tawar, dalam pemahaman urang Banjar dimaknai sebagai kemurnian. Sedangkan esensi dari warna putih dan rasa tawar nasi ketan itu mengibaratkan anak manjadi suci tanpa rasa atau dosa apapun. Dari segi kelengketan ketan juga mengandung makna kelengketan tali silaturahmi kepada sesama, kemakmuran dan kerukunan.

Gula memuat maksud ketika anak sudah bisa bicara atau ketika besar kelak tutur kata si anak menjadi halus dan senantiasa berkata-kata manis (baik), garam dengan harapan agar pembawaan si anak menjadi berwibawa karena bermulut asin, maksudnya adalah apa yang dikatakannya selalu terbukti. Minyak goreng (bagi anak perempuan) ditujukan supaya si anak menjadi orang yang peka terhadap sekitarnya.

Bahan-bahan makanan dan perlengkapan pada upacara betimbang tidak hanya dimengerti secara harfiah tetapi harus ditafsirkan secara simbolik. Dengan kata lain di dalam makna harfiah atau literal, primer yang secara langsung ditunjukan. Bersamaan dengan itu ditunjukan pula makna lain yang tidak langsung, sekunder, kiasan dan hanya dapat dipahami berdasarkan makna yang pertama. Ketan, tebu dan lain-lainnya mempunyai makna berasal dari benda itu sendiri, tetapi makna itu menembus materi dari benda-benda itu. Makna simbolik Upacara batimbang yang dilakukan oleh masyarakat Banjar yang berada di Tungkal Ilir ini, jika dicermati secara saksama, maka di dalamnya mengandung nilai-nilai yang dapat dijadikan sebagai acuan dalam kehidupan bersama. Nilai-nilai itu antara lain: ketaqwaan, kesopansantunan, kewibawaan, dan kerukunan dan nilai-nilai religius lainnya.

\section{Simpulan}

Manusia adalah makhluk budaya dan bersimbol, simbol itu terefleksi dengan perilaku-perilaku masyarakat, kemudian membentuk sistem nilai yang terkandung dalam adat istiadat suatu budaya tertentu. Upacara batimbang merupakan tindakan simbolis dan sebagai perwujudan dari makna religius dan sarana untuk mengungkapkan sikap-sikap religius masyarakat Banjar. Bagi urang Banjar, dunia mengandung simbolisme, dan melalui simbol inilah seseorang merenungkan kondisi manusia dan berkomunikasi dengan Tuhan. Upacara betimbang merupakan suatu model 
konsepsi tradisional urang Banjar mengenai bentuk-bentuk kepribadian, bahkan aspek-aspek kehidupan sosial seperti: makna hidup dan tujuan hidup. Adat kebiasaan pada dasarnya teruji secara alamiah dan bernilai baik, karena kebiasaan tersebut merupakan tindakan sosial yang berulang-ulang dan mengalami penguatan (reinforcement). Apabila suatu tindakan tidak dianggap baik oleh masyarakat maka ia tidak akan mengalami penguatan secara terus-menerus.

Tradisi upacara adat batimbang dilakukan sebagai suatu permohonan agar manusia diselamatkan dari gangguan dan bencana yang mengancam hidup dan kehidupannya. Melalui batimbang, manusia merasa terlindungi oleh kekuatan besar yang dipercaya sebagai kekuatan penyelamat sehingga dalam dirinya muncul hasrat untuk selalu sadar, bertobat, mendekat, bermohon, berserah diri dan semacamnya kepada kekuatan penyelamat yang dimaksud. Dalam Upacara batimbang tersebut terdapat peralatan, makanan yang akan disedekahkan, pembacaan ayat suci al-Quran, doa selamat dan doa tolak bala yang dijadikan sarana untuk menjembatani komunikasi antara manusia dengan kekuatan penyelamat yaitu Allah SWT.

\section{Daftar Pustaka}

Arikunto, Suharsini. Prosedur Penelitian. Jakarta: Bumi Aksara, 1989.

Azwar, Saifuddin. Metode Penelitian, Yogyakarta:Pustaka Pelajar, 2004.

Bustanuddin, Agus. Agama dalam Kehidupan Manusia: Pengantar Antropologi Agama. Jakarta: Rajawali Press, 2006.

Bauman, Richard, ed. Folklore, cultural performances, and popular entertainments: a communications-centered handbook. New York: Oxford University Press, 1992.

Bungin, Burhan, Metodologi Penelitian Kualitatif, Jakarta: Raja GrafindoPersada, 2006.

Budianto, Irmayanti Meliono. Ideologi Budaya. Jakarta: Yayasan Kota Kita, 2004.

Claude Lévi-Strauss. La pensée sauvage. Paris: Plon, 1962.

Cassirer, Ernest An Essay on Man. Fredericksburg: Book Crafters, 1979.

Dewan Kesenian Jambi. "'Editorial,"' Seloko: Jurnal Budaya, 1, no. 2 (2012): ix.

Dhavamony, Mariasusai Phenomenology of Religion. Rome: Gregorian University Press, 1973. 
Makna Upacara Batimbang dalam Tradisi Masyarakat Suku Banjar Kuala Tungkal, Provinsi Jambi

Eliade, Mircea. Patterns in Comparative Religion. London; New York: Sheed \& Ward, 1958.

Eliade, Mircea. The Sacred and the Profane the Nature of Religion. New York: NY Harcourt Brace, 1959.

Eliade, Mircea. Willard R Trask; Michael J Meade. Rites and symbols of initiation: the Mysteries of Birth and Rebirth. Putnam, Conn: Spring Publications, 2012.

Gooszen , A. J., A demographic history of the Indonesian archipelago, 18801942, KITLV Press, ISBN 90-6718-128-5, 9789067181280 , 1999.

Guibernau, M. dan Rex, J, The Ethnicity Reader: Nationalism, Multiculturalism and Migration. London: Polity Press, 2010.

Koentjaraningrat, Pengantar Antropologi. Jakarta: Rineka Cipta, 2002. Indonesia, 1987. Sejarah Teori Antropologi I, Jakarta: Universitas

Malinowski, Bronislaw. Sex, Culture, and Myth. New York: Harcourt, Brace \& World, 1962.

Meolong, Lexy J. Penelitian Kualitatif, Bandung: Remaja Rosda Karya, 2001.

Muhadjir, Noeng, Metodologi Penelitian Kualitatif, Yogyakarta: Rake, 1996.

Mulder, Niels, Kebatinan dan Hidup Sehari-hari Orang Jawa: Kelangsungan dan Perubahan Kulturil. Jakarta: PT Gramedia, 1984.

Parekh, B. Rethinking Multiculturalism: Cultural Diversity and Political Theory. Harvard: Harvard University Press, 2002.

Pederson, P. Multiculturalism as a fourth force. London: Routledge, 1998.

Philips, A. .Multiculturalism without culture. Princeton: Princeton University Press, 2009.

Spraddley, James P., Etnografi, Yogyakarta: Tiara Wacana, 2006.

Sunarto, Kamanto, Pengantar Sosiologi Edisi Revisi. Jakarta: FE-UI, 2004.

Siahaan, Hotman M, Pengantar Ke Arah Sejarah dan Teori Sosiologi,Jakarta: Erlangga, 1986.

Sugiono, Metode Penelitian Kuantitatif Kualitatif dan R $\approx D$, Bandung:Alfabeta, cet.12, 2011.

Subagyo, Joko, Metode penelitian, Jakarta:Rineka Cipta, 2004.

Turner,Victror V, Betwixt and Between: The Liminal Period in Rites de Passage, Warner Modular Pbl, 1964. 
M. Syahran Jailani dan Nurhasanah

Weber, Max, Economy and Society, ed. Guenther Roth and Claus Wittich,vol.3. New York: IrvingM. Zeitlin, Memahami Kembali Sosiologi, Yogyakarta: Gadjah Mada Press, 1998. 